\title{
Teori Belajar Menurut Aliran Psikologi Humanistik Serta Implikasinya Dalam Proses Belajar dan Pembelajaran
}

\author{
Sulaiman Sulaiman ${ }^{1}$, Neviyarni. $S^{2}$ \\ ${ }^{1,2}$ Universitas Negeri Padang \\ Email: sulaiman@fis.unp.ac.id
}

\begin{abstract}
Abstrak
Psikologi humanistik memberi perhatian atas guru sebagai fasilitator untuk memberi kemudahan belajar dan berbagai kualitas fasilitator. Implikasi kecerdasan ganda sebagai bagian dari teori humanistik adalah sebagai berikut: Pendidikan harus memerhatikan semua kemampuan intelektual, pendidikan harusnya individual, memotivasi siswa, sekolah memfasilitasi siswa mengembangkan inteligensi ganda, evaluasi proses harus lebih kontekstual, proses pembelajaran dapat terjadi dimana dan kapan saja. Psikologi humanistik sangat relevan dengan dunia pendidikan, karena aliran ini selalu mendorong peningkatan kualitas diri manusia melalui penghargaannya terhadap potensi-potensi positif yang ada pada setiap insan. Seiring dengan perubahan dan tuntutan zaman, proses pendidikan pun senantiasa berubah. Dengan adanya perubahan dalam strategi pendidikan dari waktu ke waktu, humanistik memberikan arahan yang signifikan dalam pencapaian tujuan pendidikan. Teori belajar humanistik merupakan proses belajar yang harus berhulu dan bermuara pada manusia itu sendiri. Dalam teori belajar humanistik, belajar dianggap berhasil jika si pelajar memahami lingkungannya dan dirinya sendiri. Siswa dalam proses belajarnya harus berusaha agar lambat laun ia mampu mencapai aktualisasi diri dengan sebaik-baiknya.
\end{abstract}

Kata kunci: Teori Belajar, Humanistik, Implikasi

\begin{abstract}
Humanistic psychology pays attention to teachers as facilitators to provide ease of learning and various qualities of facilitators. The implications of multiple intelligence as part of humanistic theory are as follows: Education must pay attention to all intellectual abilities, education should be individual, motivate students, schools facilitate students to develop multiple intelligences, process evaluation must be more contextual, the learning process can occur anywhere and anytime. Humanistic psychology is very relevant to the world of education, because this flow always encourages the improvement of the quality of human beings through its appreciation of the positive potentials that exist in every human being. Along with the changes and demands of the times, the educational process is always changing. With changes in educational strategies over time, humanism provides significant direction in achieving educational goals. Humanistic learning theory is a learning process that must originate and end in humans themselves. In humanistic learning theory, learning is considered successful if the student understands his environment and himself. Students in the learning process must try to gradually achieve self-actualization as well as possible.
\end{abstract}

Keywords: Learning Theory, Humanistic, Implications

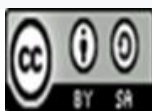

Received: February 25, $2021 \quad$ Revised: March 30, $2021 \quad$ Accepted: March 31,2021 


\section{Pendahuluan}

Aliran humanistik muncul pada tahun 1940-an sebagai reaksi ketidakpuasan terhadap pendekatan psikoanalisa dan behavioristik. Sebagai sebuah aliran dalam psikologi, aliran ini boleh dikatakan relatif masih muda, bahkan beberapa ahlinya masih hidup dan terus-menerus mengeluarkan konsep yang relevan dengan bidang pengkajian psikologi, yang sangat menekankan pentingnya kesadaran, aktualisasi diri, dan hal-hal yang bersifat positif tentang manusia.

Menurut teori humanistik, proses belajar harus dimulai dan ditujukan untuk kepentingan memanusiakan manusia itu sendiri. Oleh sebab itu, teori belajar humanistik sifatnya lebih abstrak dan lebih mendekati bidang kajian filsafat, teori kepribadian, dan psikoterapi, dari pada bidang kajian psikologi belajar. Teori humanistik sangat mementingkan isi yang dipelajari dari pada proses belajar itu sendiri serta lebih banyak berbiacara tentang konsep-konsep pendidikan untuk membentuk manusia yang dicita-citakan, serta tentang proses belajar dalam bentuk yang paling ideal.

Faktor motivasi dan pengalaman emosional sangat penting dalam peristiwa belajar, sebab tanpa motivasi dan keinginan dari pihak si belajar, maka tidak akan terjadi asimilasi pengetahuan baru ke dalam struktur kognitif yang telah dimilikinya. Teori humanistic berpendapat bahwa teori belajar apapun dapat dimanfaatkan, asal tujuannya untuk memanusiakan manusia yaitu mencapai aktualisasi diri, pemahaman diri, serta realisasi diri orang yang belajar, secara optimal.

Teori humanistik bersifat sangat eklektik yaitu memanfaatkan atau merangkumkan berbagai teori belajar dengan tujuan untuk memanusiakan manusia dan mencapai tujuan yang diinginkan karena tidak dapat disangkal bahwa setiap teori mempunyai kelebihan dan kekurangan.

\section{Hasil dan Pembahasan}

\section{Pengertian Teori Psikologi Humanistik}

Teori Psikologi humanistik ini berusaha memahami perilaku belajar dari sudut pandang pelakunya, bukan dari sudut pandang pengamatnya. Tujuan utama para pendidik menurut humanistik adalah membantu peserta didik untuk mengembangkan dirinya, yaitu membantu masing-masing individu untuk mengenal diri mereka sendiri sebagai manusia yang unik dan membantu dalam mewujudkan potensi-potensi yang ada dalam diri mereka. Jadi, teori belajar humanisme adalah suatu teori dalam pembelajaran yang mengedepankan bagaimana memanusiakan manusia serta peserta didik mampu mengembangkan potensi dirinya.

Menurut Ratna Wilis Dahar (Dahar, 2011) teori belajar humanisme menganggap bahwa keberhasilan belajar terjadi jika peserta didik memahami lingkungannya dan dirinya sendiri. Teori belajar ini berusaha memahami perilaku belajar dari sudut pandang pelakunya,bukan dari sudut pandang pengamatnya.Peran pendidik adalah membantu peserta didik untuk mengembangkan dirinya,yaitu membantu masing-masig individu untuk mengenal diri mereka sendiri sebagai manusia yang unik dan membantu mereka dalam mewujudkan potensi-potensi yang ada dalam diri mereka.

Sedangkan Herpratiwi (Herpratiwi, 2009) mengatakan titik awal timbulnya psikologi humanistik terjadi pada akhir tahun 1940-an yaitu munculnya suatu perspektif psikologi baru. Orang-orang yang terlibat dalam penerapan psikologilah yang berjasa dalam pengembangan ini. Misalnya; ahli-ahli psikologi klinik, pekerja-pekerja sosial, konselor, bukan merupakan hasil penelitian dalam bidang proses belajar. Gerakan ini berkembang dan kemudian dikenalkan dengan psikologi humanistis, eksternal, perseptual atau fenomenologikal. Psikologi ini berusaha memahami perilaku seseorang dari sudut perilaku (behavior), bukan dari pengamat observer. 
Dalam dunia pendidikan aliran humanisme muncul pada tahun 1960 sampai dengan 1970-an dan mungkin perubahan-perubahan dan inovasi yang terjadi selama dua dekade yang terakhir pada abad ke-20 ini pun juga akan menuju pada arah ini

Lebih lanjut Herpratiwi (Herpratiwi, 2009) mengaitkan bahwa perhatian psikologi humanistik terutama tertuju pada masalah bagaimana tiap-tiap individu dipengaruhi dan dibimbing oleh maksud-maksud pribadi yang mereka hubungkan kepada pengalamanpengalaman mereka sendiri. Menurut para pendidik aliran humanistis penyusunan dan penyajian materi pelajaran harus sesuai dengan perasaan dan perhatian siswa. Gerakan munculnya psikologi humanistik disebabkan oleh semacam kesadaran bersama beranggapan bahwa pada dasarnya tidak ada teori psikologi yang berkemampuan menjelaskan manusia sebagai suatu totalitas dan yang sewajarnya mengfungsikan manusia. Mereka meyakini bahwa tiap individu pada dasarnya mempunyai kapasitas serta dorongan sendiri untuk mengembangkan potensi kemanusiaannya

Aliran humanistik menegaskan, para pendidik sebaiknya melihat kebutuhan yang lebih tinggi dan merencanakan pendidikan dan kurikulum untuk memenuhi kebutuhan-kebutuhan ini (Aradea and Harapan 2019). Beberapa psikolog humanistik melihat bahwa manusia mempunyai keinginan alami untuk berkembang untuk menjadi lebih baik dan juga belajar Teori humanisme berfokus pada sikap dari kondisi manusia yang mencakup kesanggupan untuk menyadari diri, bebas memilih untuk menentukan nasib sendiri, kebebasan dan bertanggung jawab, kecemasan sebagai suatu unsur dasar pencarian.

Hal di atas senada dengan yang dikatakan oleh Uno (B. Uno, 2008) mengatakan bahwa perkembangan pribadi yang muncul berdasarkan keunikan masing-masing individu. Teori ini berfokus pada saat sekarang dan menjadi apa seorang itu dimasa depan. Pendekatan ini menyajikan kondisi untuk memaksimalkan kesadaran diri dan perkembangan. Menghapus penghambat aktualisasi potensi pribadi. Membantu siswa menemukan dan menggunakan kebebasan memilih dengan memperluas kesadaran diri dan bertanggung jawab atas arah kehidupanya sendiri (Nursikin, 2016). Teori belajar ini berusaha memahami perilaku belajar dari sudut pandang pelakunya, bukan dari sudut pandang pengamatnya.

Begitu juga Herpratiwi (Herpratiwi, 2009) mengatakan bahwa keleluasaan untuk memilih apa yang akan dipelajari dan kapan serta bagaimana mereka akan mempelajarinya merupakan ciri utama pendekatan humanisme. Bertujuan untuk membantu siswa menjadi self-directed serta self-motivated leaner. Penganut paham ini yakin bahwa siswa akan bersedia melakukan banyak hal apabila mereka memiliki motivasi yang tinggi dan mereka diberi kesempatan untuk menentukan apa yang mereka inginkan. Pengertian humanisme yang beragam membuat batasan-batasan aplikasinya dalam dunia pendidikan mengundang berbagai macam arti pula. Kata humanisme dalam pendidikan, dalam artikel "what is humanistic education?", Krischenbaum menyatakan bahwa sekolah, kelas, atau guru dapat dikatakan bersifat humanistik dalam pendidikan. Ide mengenai pendekatan-pendekatan ini terangkum dalam psikologi humanisme

Dengan demkian konsep pendekatan humanistik dalam pendidikan menekankan pada perkembangan positif. Pendekatan yang berfokus pada potensi manusia untuk mencari dan menemukan kemampuan yang mereka punya dan mengembangkan kemampuan tersebut. Hal ini mencakup kemampuan interpersonal sosial dan metode untuk pengembangan diri yang ditujukan untuk memperkaya diri, menikmati keberadaan hidup dan juga masyarakat. Keterampilan atau kemampuan membangun diri secara positif ini menjadi sangat penting dalam pendidikan karena keterkaitannya dengan keberhasilan akademik

\section{Tujuan Belajar Menurut Teori Psikologi Humanistik}

Menurut teori humanistik belajar harus dimulai dan ditujukan untuk kepentingan memanusiakan manusia. Teori belajar humanistik sifatnya abstrak dan lebih mendekaji kajian 
filsafat. Teori ini lebih banyak berbicara tentang konsep-konsep. Dalam teori pembelajaran humanistik, belajar merupakan proses yang dimulai dan ditujukan untuk kepentingan memanusiakan manusia. Memanusiakan manusia, yakni untuk mencapai aktualisasi diri, pemahaman diri, serta realisasi diri orang yang belajar secara optimal. Dal hal ini, maka teori humanistik ini bersifat eklektik (memanfaatkan / merangkum semua teori apapun dengan tujuan untuk memanusiakan manusia) (Eggy, 2020).

Salah satu ide penting dalam teori belajar humanistik adalah siswa harus mempunyai kemampuan untuk mengarahkan sendiri perilakunya dalam belajar (self regulated learning), apa yang akan dipelajari dan sampai tingkatan mana, kapan dan bagaimana mereka akan belajar. Siswa belajar mengarahkan sekaligus memotivasi diri sendiri dalam belajar daripada sekedar menjadi penerima pasif dalam proses belajar. Siswa juga belajar menilai kegunaan belajar itu bagi dirinya sendiri.

Aliran humanistik memandang belajar sebagai sebuah proses yang terjadi dalam individu yang melibatkan seluruh bagian atau domain yang ada yang meliputi domain kognitif, afektif dan psikomotorik (Rahmasari, 2012). Dengan kata lain, pendekatan humanistik menekankan pentingnya emosi atau perasaan, komunikasi terbuka, dan nilai-nilai yang dimiliki oleh setiap siswa. Untuk itu, metode pembelajaran humanistik mengarah pada upaya untuk mengasah nilainilai kemanusiaan siswa. Guru, oleh karenanya, disarankan untuk menekankan nilai-nilai kerjasama, saling membantu, dan menguntungkan, kejujuran dan kreativitas untuk diaplikasikan dalam proses pembelajaran.

Menurut Sumanto (Abdah, 2019) tujuan teori humanistik lebih menunjuk pada ruh atau spirit selama proses pembelajaran yang mewarnai metode-metode yang diterapkan. Peran guru dalam pembelajaran humanistik adalah menjadi fasilitator bagi para peserta didik sedangkan guru memberikan motivasi, kesadaran mengenai makna belajar dalam kehidupan peserta didik. Guru memfasilitasi pengalaman belajar kepada peserta didik dan mendampingi peserta didik untuk memperoleh tujuan pembelajaran.

Peserta didik berperan sebagai pelaku utama (student center) yang memaknai proses pengalaman belajarnya sendiri. Diharapkan peserta didik memahami potensi diri, mengembangkan potensi dirinya secara positif dan meminimalkan potensi diri yang bersifat negatif.

Tujuan pembelajaran lebih kepada proses belajarnya daripada hasil belajar (Sylvia, Anwar, \& Khairani, 2019). Adapun proses yang umumnya dilalui adalah: (1) Merumuskan tujuan belajar yang jelas. (2) Mengusahakan partisipasi aktif peserta didik melalui kontrak belajar yang bersifat jelas, jujur dan positif. (3) Mendorong peserta didik untuk mengembangkan kesanggupan peserta didik untuk belajar atas inisiatif sendiri. (4) Mendorong peserta didik untuk peka berpikir kritis, memaknai proses pembelajaran secara mandiri. (5) Peserta didik di dorong untuk bebas mengemukakan pendapat, memilih pilihannya sendiri, melakukkan apa yang diinginkan dan menanggung resiko dari perilaku yang ditunjukkan. (6) Guru menerima peserta didik apa adanya, berusaha memahami jalan pikiran peserta didik, tidak menilai secara normatif tetapi mendorong peserta didik untuk bertanggungjawab atas segala resiko perbuatan atau proses belajarnya. (7) Memberikan kesempatan murid untuk maju sesuai dengan kecepatannya. (8) Evaluasi diberikan secara individual berdasarkan perolehan prestasi peserta didik.

Pembelajaran berdasarkan teori humanistik ini tepat untuk diterapkan. Keberhasilan aplikasi ini adalah peserta didik merasa senang bergairah, berinisiatif dalam belajar dan terjaadi perubahan pola pikir, perilaku dan sikap atas kemauan sendiri (Abdah, 2019). Peserta didik diharapkan menjadi manusia yang bebas, berani, tidak terikat oleh pendapat orang lain dan mengatur pribadinya sendiri secara bertanggungjawab tanpa mengurangi hak-hak orang lain atau melanggar aturan, norma, disiplin atau etika yang berlaku.

Dengan demikan menurut teori humanistik, tujuan belajar adalah untuk memanusiakan manusia. Proses belajar dianggap berhasil jika si pelajar memahami lingkungannya dan dirinya 
sendiri. Siswa dalam proses belajarnya harus berusaha agar lambat laun ia mampu mencapai aktualisasi diri dengan sebaik-baiknya. Jadi Tujuan utama pendidik adalah membantu siswa untuk mengembangkan dirinya, yaitu membantu masing-masing individu untuk mengenal diri mereka sendiri sebagai manusia yang unik dan membantu dalam mewujudkan potensi-potensi yang ada dalam diri mereka.

\section{Tokoh-Tokoh Teori Humanistik}

\section{Abraham Maslow}

Abraham H. Maslow (selanjutnya ditulis Maslow) adalah tokoh yang menonjol dalam psikologi humanistik. Karyanya di bidang pemenuhan kebutuhan berpengaruh sekali terhadap upaya memahami motivasi manusia. Sebagian dari teorinya yang penting didasarkan atas asumsi bahwa dalam diri manusia terdapat dorongan positif untuk tumbuh dan kekuatankekuatan yang melawan atau menghalangi pertumbuhan (Rachmahana, 2008). Maslow berpendapat, bahwa manusia memiliki hierarki kebutuhan yang dimulai dari kebutuhan jasmaniah-yang paling asasi- sampai dengan kebutuhan tertinggi yakni kebutuhan estetis (Wasitohadi, 2012). Kebutuhan jasmaniah seperti makan, minum, tidur dan sex menuntut sekali untuk dipuaskan. Apabila kebutuhan ini terpuaskan, maka muncullah kebutuhan keamanan seperti kebutuhan kesehatan dan kebutuhan terhindar dari bahaya dan bencana. Berikutnya adalah kebutuhan untuk memiliki dan cinta kasih, seperti dorongan untuk memiliki kawan dan berkeluarga, kebutuhan untuk menjadi anggota kelompok, dan sebagainya. Ketidakmampuan memenuhi kebutuhan ini dapat mendorong seseorang berbuat lain untuk memperoleh pengakuan dan perhatian, misalnya dia menggunakan prestasi sebagai pengganti cinta kasih. Berikutnya adalah kebutuhan harga diri, yaitu kebutuhan untuk dihargai, dihormati, dan dipercaya oleh orang lain.

Apabila seseorang telah dapat memenuhi semua kebutuhan yang tingkatannya lebih rendah tadi, maka motivasi lalu diarahkan kepada terpenuhinya kebutuhan aktualisasi diri, yaitu kebutuhan untuk mengembangkan potensi atau bakat dan kecenderungan tertentu. Bagaimana cara aktualisasi diri ini tampil, tidaklah sama pada setiap orang.

Sesudah kebutuhan tersebut, muncul kebutuhan untuk tahu dan mengerti, yakni dorongan untuk mencari tahu, memperoleh ilmu dan pemahaman. Sesudahnya, Maslow berpendapat adanya kebutuhan estetis, yakni dorongan keindahan, dalam arti kebutuhan akan keteraturan, kesimetrisan dan kelengkapan. Maslow membedakan antara empat kebutuhan yang pertama dengan tiga kebutuhan yang kemudian. Keempat kebutuhan yang pertama disebutnya Deficiency Need (kebutuhan yang timbul karena kekurangan), dan pemenuhan kebutuhan ini pada umumnya bergantung pada orang lain. Sedangkan ketiga kebutuhan yang lain dinamakan growth need (kebutuhan untuk tumbuh) dan pemenuhannya lebih bergantung pada manusia itu sendiri.

Implikasi dari teori Maslow dalam dunia pendidikan sangat penting. Dalam proses belajarmengajar misalnya, guru mestinya memperhatikan teori ini. Apabila guru menemukan kesulitan untuk memahami mengapa anak-anak tertentu tidak mengerjakan pekerjaan rumah, mengapa anak tidak dapat tenang di dalam kelas, atau bahkan mengapa anak-anak tidak memiliki motivasi untuk belajar. Menurut Maslow, guru tidak bisa menyalahkan anak atas kejadian ini secara langsung, sebelum memahami barangkali ada proses tidak terpenuhinya kebutuhan anak yang berada di bawah kebutuhan untuk tahu dan mengerti. Bisa jadi anak-anak tersebut belum atau tidak melakukan makan pagi yang cukup, semalam tidak tidur dengan nyenyak, atau ada masalah pribadi / keluarga yang membuatnya cemas dan takut, dan lain-lain.

\section{Carl Rogers}

Menurut Hadis (Budiningsih, 2005), Carl R. Rogers kurang menaruh perhatian kepada mekanisme proses belajar. Belajar dipandang sebagai fungsi keseluruhan pribadi. Mereka

Jurnal Sikola: Jurnal Kajian Pendidikan dan Pembelajaran Vol. 2, No. 3, Th. 2021 
berpendapat bahwa belajar yang sebenarnya tidak dapat berlangsung bila tidak ada keterlibatan intelektual maupun emosional peserta didik. Oleh karena itu, menurut teori belajar humanisme bahwa motivasi belajar harus bersumber pada diri peserta didik.

Roger membedakan dua ciri belajar, yaitu: (1) belajar yang bermakna dan (2) belajar yang tidak bermakna. Belajar yang bermakna terjadi jika dalam proses pembelajaran melibatkan aspek pikiran dan perasaan peserta didik, dan belajar yang tidak bermakna terjadi jika dalam proses pembelajaran melibatkan aspek pikiran akan tetapi tidak melibatkan aspek perasaan peserta didik. Kemudian muncul pertanyaan bagaimana proses belajar dapat terjadi menurut teori belajar humanisme. Orang belajar karena ingin mengetahui dunianya. Individu memilih sesuatu untuk dipelajari, mengusahakan proses belajar dengan caranya sendiri, dan menilainya sendiri tentang apakah proses belajarnya berhasil.

Menurut Roger, peranan guru dalam kegiatan belajar peserta didik menurut pandangan teori humanisme adalah sebagai fasilitator yang berperan aktif dalam: (1) membantu menciptakan iklim kelas yang kondusif agar peserta didik bersikap positif terhadap belajar, (2) membantu peserta didik untuk memperjelas tujuan belajarnya dan memberikan kebebasan kepada peserta didik untuk belajar, (3) membantu peserta didik untuk memanfaatkan dorongan dan cita-cita mereka sebagai kekuatan pendorong belajar, (4) menyediakan berbagai sumber belajar kepada peserta didik, dan (5) menerima pertanyaan dan pendapat, serta perasaan dari berbagai peserta didik sebagaimana adanya. (Budiningsih, 2005)

\section{Arthur Combs}

Perilaku internal membedakan seseorang dari yang lain. Combs berpendapat bahwa banyak guru membuat kesalahan dengan berasumsi bahwa peserta didik mau belajar apabila materi pelajarannya disusun dan disajikan sebagaimana mestinya. Padahal arti tidaklah menyatu pada materi pelajaran itu. Sehingga yang penting ialah bagaimana membawa si peserta didik untuk memperoleh arti bagi pribadinya dari materi pelajaran tersebut dan menghubungkannya dengan kehidupannya. Combs memberikan lukisan persepsi diri dalam dunia seseorang seperti dua lingkaran (besar dan kecil) yang bertitik pusat pada satu.. Lingkaran kecil (1) adalah gambaran dari persepsi diri dan lingkungan besar (2) adalah persepsi dunia. Makin jauh peristiwa-peristiwa itu dari persepsi diri makin berkurang pengaruhnya terhadap perilakunya. Jadi, hal-hal yang mempunyai sedikit hubungan dengan diri, makin mudah hal itu terlupakan.

Belajar terjadi bila mempunyai arti bagi individu. Guru tidak bisa memaksakan materi yang tidak disukai atau tidak relevan dengan kehidupan mereka. Anak tidak bisa matematika atau sejarah bukan karena bodoh tetapi karena mereka enggan dan terpaksa dan merasa sebenarnya tidak ada alasan penting mereka harus mempelajarinya. Perilaku buruk itu sebenarnya tak lain hanyalah dari ketidakmampuan seseorang untuk melakukan sesuatu yang tidak akan memberikan kepuasan baginya. Untuk itu guru harus memahami perilaku peserta didik dengan mencoba memahami dunia persepsi peserta didik tersebut sehingga apabila ingin merubah perilakunya, guru harus berusaha merubah keyakinan atau pandangan peserta didik yang ada.

\section{Kolb (Experiential Learning Theory)}

Experiential Learning merupakan model pembelajaran yang sangat memperhatikan perbedaan atau keunikan yang dimiliki siswa, karenanya model ini memiliki tujuan untuk mengakomodasi perbedaan dan keunikan yang dimiliki oleh masing-masing individu. Dengan mengamati inventori gaya belajar (learning style inventory) yang dikembangkan masing-masing siswa. Teori ini dikembangkan oleh David Kolb pada sekitar awal tahun 1980-an. Dalam teorinya, Kolb mendefinisikan belajar sebagai proses dimana pengetahuan diciptakan melalui transformasi pengalaman. Pengetahuan dianggap sebagai perpaduan antara memahami dan mentransformasi pengalaman. Experiential Learninng Theory kemudian menjadi dasar model pembelajaran experiential learning yang menekankan pada sebuah model pembelajaran yang 
holistik dalam proses belajar. Pengalaman kemudian mempunyai peran sentral dalam proses belajar.

Lebih lanjut, Kolb membagi belajar menjadi 4 tahap: (1) Tahap pengamalan konkrit (Concrete Experience). Merupakan tahap paling awal, yakni seseorang mengalami sesuatu peristiwa sebagaimana adanya (hanya merasakan, melihat, dan menceritakan kembali peristiwa itu). Dalam tahap ini seseorang belum memiliki kesadaran tentang hakikat peristiwa tersebut, apa yang sesungguhnya terjadi, dan mengapa hal itu terjadi. (2) Tahap Pengalaman Aktif dan Reflektif (Reflection Observation). Pada tahap ini sudah ada observasi terhadap peristiwa yang dialami, mencari jawaban, melaksanakan refleksi, mengembangkan pertanyaan- pertanyaan bagaimana peristiwa terjadi, dan mengapa terjadi. (3) Tahap Konseptualisasi (Abstract Conseptualization). Pada tahap ini seseorang sudah berupaya membuat sebuah abstraksi, mengembangkan suatu teori, konsep, prosedur tentang sesuatu yang sedang menjadi objek perhatian. (4) Tahap Eksperimentasi Aktif (Active Experimentation). Pada tahap ini sudah ada upaya melakukan eksperimen secara aktif, dan mampu mengaplikasikan konsep, teori ke dalam situasi nyata. Pada dasarnya, tahap-tahap tersebut berlangsung diluar kesadaran orang yang belajar, (begitu saja terjadi).

David Kolb mengklasifikasikan gaya belajar seseorang menjadi empat kategori sebagai berikut:

a. Converger. Tipe ini lebih suka belajar jika menghadapi soal yang mempunyai jawaban tertentu. Orang dengan tipe ini tidak emosional dan lebih suka menghadapi benda daripada manusia. Mereka tertarik pada ilmu pengetahuan alam dan teknik.

b. Diverger Tipe ini memandang sesuatu dari berbagai segi dan kemudian menghubungkannya menjadi suatu kesatuan yang utuh. Orang dengan tipe ini lebih suka berhubungan dengan manusia. mereka lebih suka mendalami bahasa, kesusastraan, sejarah dan ilmu-ilmu sosial lainnya.

c. Assimilation. Tipe ini lebih tertarik pada konsep-konsep yang abstrak. Orang dengan tipe ini tidak terlalu memperhatikan penerapan praksis dari ide-ide mereka. Bidang studi yang diminati adalah bidang keilmuan (science) dan matematika.

d. Accomodator. Tipe ini berminat pada penngembangan konse-konsep. Orang dengan tipe ini berminat pada hal-hal yang konkret dan eksperimen. Bidang studi yang sesuai untuk tipe ini adalah lapangan usaha dan teknik sedangkan pekerjaan yang sesuai antara lain penjualan dan pemasaran.

Dari keempat gaya tersebut, tidak berarti manusia harus digolongkan secara permanen dalam masing-masing kategori. Menurut Kolb, belajar merupakan suatu perkembangan yang melalui tiga fase yaitu, pengumpulan pengetahuan (acquisition), pemusatan perhatian pada bidang tertentu (specialization) dan menaruh minat pada bidang yang kurang diminati sehingga muncul minat dan tujuan hidup baru. Sehingga, walaupun pada tahap awal individu lebih dominan pada gaya belajar tertentu, namun pada proses perkembangannya diharapkan mereka dapat mengintegrasikan semua kategori belajar.

\section{Honey dan Mumford}

Pandangan tentang belajar Honey dan Mumford banyak dipengaruhi oleh Kolb. Mereka kemudian menggolong-golongkan orang belajar menjadi empat macam golongan yaitu: (1) Kelompok aktivis, karakteristiknya yaitu senang melibatkan diri dan berpartisipasi dalam suatu kegiatan untuk meperoleh pengalaman yang baru dan mudah diajak berdialog. Mempunyai pemikiran yang terbuka dan menghargai pendapat orang lain. Mudah percaya pada orang lain namun kurang pertimbangan yang matang dalam melangkah. (2) Kelompok reflektor, karakteristiknya yaitu sangat berhati-hati dan penuh pertimbangan dalam mengambil keputusan, tidak mudah dipengaruhi orang lain serta cenderung bersifat konservatif. (3) Kelompok teoris: karakteristiknya yaitu sangat kritis, suka menganalisis, selalu berpikir rasional dengan 
menggunakan penalaran. Kemudian Segala sesuatu dikembalikan pada teori dan konsep, tidak menyukai pendapat/penilaian yang subyektif, Tidak menyukai hal-hal yang spekulatif, mempunyai pendirian yang kuat serta tidak mudah dipengaruhi orang lain. (4) Kelompok pragmatis, karakteristiknya yaitu, Praktis, tidak suka bertele-tele dengan suatu teori/konsep. Sesuatu dikatakan berguna apabila dapat dilaksakanan/ dipraktekkan bagi kehidupan manusia

\section{Habermas}

Menurut Habernas, belajar baru akan tejadi jika ada interaksi antara individu dengan lingkungannya. Ia membagi tipe belajar menjadi tiga, yaitu: (1) Belajar teknis (technical learning), yaitu belajar bagaimana seseorang dapat berinteraksi dengan lingkungan alamnya secara benar. (2) Belajar praktis (practical learning), yaitu belajar bagaimana seseorang dapat berinteraksi dengan lingkungan sosialnya, yaitu dengan orang-orang di sekelilingnya dengan baik. (3) Belajar emansipatoris (emancipatory learning), yaitu belajar yang menekankan upaya agar seseorang mencapai suatu pemahaman dan kesadaran tinggi akan terjadinya perubahan atau transformasi budaya dengan lingkungan sosialnya.

\section{Bloom dan Krathwohl}

Bloom dan Krathwohl menekankan perhatiannya pada apa yang mesti dikuasai oleh individu (sebagai tujuan belajar), setelah melalui peristiwa-peristiwa belajar. Tujuan belajarnya dikemukakan dengan sebutan Taksonomi Bloom, yaitu:

a. Domain kognitif, terdiri atas 6 tingkatan, yaitu: 1) Pengetahuan 2) Pemahaman 3) Aplikasi 4) Analisis 5) Evaluasi 6) Mencipta

b. Domain psikomotor, terdiri atas 5 tingkatan, yaitu: 1) Peniruan 2) Penggunaan 3) Ketepatan 4) Perangkaian 5) Naturalisasi

c. Domain afektif, terdiri atas 5 tingkatan, yaitu: 1) Pengenalan 2) Merespon 3) Penghargaan 4) Pengorganisasian 5) Pengalaman

\section{Prinsip dasar Teori Humanistik}

Menurut Dakir (Dakir, 1993), Roger sebagai ahli dari teori belajar humanisme mengemukakan beberapa prinsip belajar yang penting yaitu:

1. Manusia itu memiliki keinginan alamiah untuk belajar, memiliki rasa ingin tahu alamiah terhadap dunianya, dan keinginan yang mendalam untuk mengeksplorasi dan asimilasi pengalaman baru

2. Belajar akan cepat dan lebih bermakna bila bahan yang dipelajari relevan dengan kebutuhan peserta didik

3. belajar dapat di tingkatkan dengan mengurangi ancaman dari luar,

4. belajar secara partisipasif jauh lebih efektif dari pada belajar secara pasif dan orang belajar lebih banyak bila belajar atas pengarahan diri sendiri,

5. belajar atas prakarsa sendiri yang melibatkan keseluruhan pribadi, pikiran maupun perasaan akan lebih baik dan tahan lama, dan

6. kebebasan, kreatifitas, dan kepercayaan diri dalam belajar dapat ditingkatkan dengan evaluasi diri orang lain tidak begitu penting. adalah,

Sedangkan Alwasilah (Aziz, 1995) mengatakan prinsip belajar menurut teori humanistik

1. Pendekatan humanistik menganggap peserta didik sebagai $a$ whole person atau orang sebagai suatu kesatuan. Dengan kata lain, pembelajaran tidak hanya mengajarkan materi atau bahan ajar yang menjadi sasaran, tetapi juga membantu peserta didik mengembangkan diri mereka sebagai manusia.

2. Keyakinan tersebut telah mengarahkan munculnya sejumlah teknik dan metodologi pembelajaran yang menekankan aspek humanistik pembelajaran. Dalam metodologi semacam itu, pengalaman peserta didik adalah yang terpenting dan perkembangan

Jurnal Sikola: Jurnal Kajian Pendidikan dan Pembelajaran Vol. 2, No. 3, Th. 2021 
kepribadian mereka serta penumbuhan perasaan positif dianggap penting dalam pembelajaran mereka. Pendekatan humanistik mengutamakan peranan peserta didik dan berorientasi pada kebutuhan. Menurut pendekatan ini, materi atau bahan ajar harus dilihat sebagai suatu totalitas yang melibatkan orang secara utuh, bukan sekedar sebagai sesuatu yang intelektual semata-mata. Seperti halnya guru, peserta didik adalah manusia yang mempunyai kebutuhan emosional, spritual, maupun intelektual. Peserta didik hendaknya dapat membantu dirinya dalam proses belajar mengajar. Peserta didik bukan sekedar penerima ilmu yang pasif.

\section{Kelebihan dan Kekurangan Teori Belajar Humanisme}

\section{Kelebihan teori Humanisme}

Menurut Asri Budiningsih (Budiningsih, 2005) kelebihan teori humanistik adalah,

a. Teori ini cocok untuk diterapkan dalam materi pembelajaran yang bersifat pembentukan kepribadian, hati nurani, perubahan sikap, dan analisis terhadap fenomena sosial.

b. Menurut aliran humanisme: individu itu cenderung mempunyai kemampuan / keinginan untuk berkembang dan percaya pada kodrat biologis dan ciri lingkungan

c. Indikator dari keberhasilan aplikasi ini adalah siswa merasa senang bergairah, berinisiatif dalam belajar dan terjadi perubahan pola pikir, perilaku dan sikap atas kemauan sendiri.

d. Siswa diharapkan menjadi manusia yang bebas, tidak terikat oleh pendapat orang lain dan mengatur pribadinya sendiri secara bertanggung jawab tanpa mengurangi hak-hak orang lain atau melanggar aturan, norma, disiplin atau etika yang berlaku.

e. Aliran humanisme tidak menyetujui sifat pesimisme, dalam aliran humanisme individu itu memiliki sifat yang optimistik

f. Teori Humanistik sangat membantu para pendidik dalam memahami arah belajar pada dimensi yang lebih luas, sehingga upaya pembelajaran apapun dan pada konteks manapun akan selalu diarahkan dan dilakukan untuk mencapai tujuannya. Ide-ide, konsep-konsep, taksonomi-taksonomi tujuan yang dirumuskan dapat membantu para pendidik dan guru untuk memahami hakikat kejiwaan manusia.

\section{Kekurangan teori humanism}

Menurut Asri Budiningsih (Budiningsih, 2005) kekurangan teori humanistik adalah

a. Siswa yang tidak mau memahami potensi dirinya akan ketinggalan dalam proses belajar.

b. Terlalu memberi kebebasan pada siswa.

c. Teori humanisme terlalu optimistik secara naif dan gagal untuk memberikan pendekatan pada sisi buruk dari sifat alamiah manusia

d. Teori humanisme, seperti halnya teori psikodinamik, tidak bisa diuji dengan mudah

e. Banyak konsep dalam psikologi humanisme, seperti misalnya orang yang telah berhasil mengaktualisasikan dirinya, ini masih buram dan subjektif.

f. Beberapa kritisi menyangkal bahwa konsep ini bisa saja mencerminkan nilai dan idealisme Maslow sendiri.

g. Psikologi humanisme mengalami pembiasan terhadap nilai individualistis

h. Teori humanisme ini dikritik karena sukar digunakan dalam konteks yang lebih praktis. Teori ini dianggap lebih dekat dengan dunia filsafat daripada dunia pendidikan.

i. Aplikasi teori humanisme dalam pembelajaran, guru lebih mengarahkan siswa untuk berpikir induktif, mementingkan pengalaman serta membutuhkan keterlibatan siswa secara aktif dalam proses belajar.

j. Teori humanisme masih sukar diterjemahkan kedalam langkah-langkah yang praktis dan operasional

Fasilitas Dalam Teori Belajar Humanistik 
Penerapan teori humanistik lebih menunjuk pada ruh atau spirit selama proses pembelajaran yang mewarnai metode-metode yang diterapkan. Peran guru dalam pembelajaran humanistik adalah menjadi fasilitator bagi para peserta didik sedangkan guru memberikan motivasi, kesadaran mengenai makna belajar dalam kehidupan peserta didik (Aradea \& Harapan, 2019). Guru memfasilitasi pengalaman belajar kepada peserta didik dan mendampingi peserta didik untuk memperoleh tujuan pembelajaran.

Menurut Dakir (Dakir, 1993) psikologi humanistik memberi perhatian atas guru sebagai fasilitator. Berikut ini adalah berbagai cara untuk memberi kemudahan belajar dan berbagai kualitas fasilitator, yaitu: (1) Fasilitator sebaiknya memberi perhatian kepada penciptaan suasana awal, situasi kelompok, atau pengalaman kelas. (2) Fasilitator membantu untuk memperoleh dan memperjelas tujuan-tujuan perorangan di dalam kelas dan juga tujuan-tujuan kelompok yang bersifat umum. (3) Dia mempercayai adanya keinginan dari masing-masing peserta didik untuk melaksanakan tujuan-tujuan yang bermakna bagi dirinya, sebagai kekuatan pendorong, yang tersembunyi di dalam belajar yang bermakna tadi. (4) Dia mencoba mengatur dan menyediakan sumber-sumber untuk belajar yang paling luas dan mudah dimanfaatkan para peserta didik untuk membantu mencapai tujuan mereka. (5) Dia menempatkan dirinya sendiri sebagai suatu sumber yang fleksibel untuk dapat dimanfaatkan oleh kelompok. (6) Di dalam menanggapi ungkapan-ungkapan di dalam kelompok kelas, dan menerima baik isi yang bersifat intelektual dan sikap-sikap perasaan dan mencoba untuk menanggapi dengan cara yang sesuai, baik bagi individual ataupun bagi kelompok. (7) Bilamana cuaca penerima kelas telah mantap, fasilitator berangsur-sngsur dapat berperanan sebagai seorang peserta didik yang turut berpartisipasi, seorang anggota kelompok, dan turut menyatakan pendangannya sebagai seorang individu, seperti peserta didik yang lain. (8) Dia mengambil prakarsa untuk ikut serta dalam kelompok, perasaannya dan juga pikirannya dengan tidak menuntut dan juga tidak memaksakan, tetapi sebagai suatu andil secara pribadi yang boleh saja digunakan atau ditolak oleh peserta didik (9) Dia harus tetap waspada terhadap ungkapan-ungkapan yang menandakan adanya perasaan yang dalam dan kuat selama belajar (10) Di dalam berperan sebagai seorang fasilitator, pimpinan harus mencoba untuk menganali dan menerima keterbatasanketerbatasannya sendiri.

Sementara itu Syaodih (Sukmadinata, 2007) mengatakan ciri-ciri guru yang fasilitatif adalah: (1) Merespon perasaan peserta didik (2) Menggunakan ide-ide peserta didik untuk melaksanakan interaksi yang sudah dirancang (3) Berdialog dan berdiskusi dengan peserta didik (4) Menghargai peserta didik (5) Kesesuaian antara perilaku dan perbuatan (6) Menyesuaikan isi kerangka berpikir peserta didik (penjelasan untuk mementapkan kebutuhan segera dari peserta didik) (7) Tersenyum pada peserta didik.

\section{Model-Model Pembelajaran Humanistik}

Berikut banyak sekali hal-hal yang merupakan aplikasi dari teori-teori humanistik, namun dalam kesempatan ini hanya akan ditampilkan sebagian aplikasi dalam proses pembelajaran, yaitu:

\section{Open Education atau Pendidikan Terbuka}

Pendidikan Terbuka adalah proses pendidikan yang memberikan kesempatan kepada murid untuk bergerak secara bebas di sekitar kelas dan memilih aktivitas belajar mereka sendiri. Guru hanya berperan sebagai pembimbing. Ciri utama dari proses ini adalah lingkungan fisik kelas yang berbeda degan kelasa tradisional, karena murid bekerja secara individual atau dalam kelompok-kelompok kecil.

Dalam proses ini di syaratkan adanya pusat-pusat belajar atau pusat-pusat kegiatan di dalam kelas yang memungkinkan murid mengeksplorasi bidang-bidang pelajaran, topik-topik, ketrampilanketrampilan atau minat-minat tertentu. Pusat ini dapat memberikan petunjuk untuk 
mempelajari suatu topik tanpa hadirnya guru dan dapat mencatat partisipasi dan kemajuan murid untuk nantinya dibicarakan dengan guru (Rachmahana, 2008). Adapun kriteria yang disyaratkan dengan model ini adalah sebagai berikut:

a. Tersedia fasilitas yang memudahkan proses belajar, artinya berbagai macam bahan yang diperlukan untuk belajar harus ada. Murid tidak dilarang untuk bergerak secara bebas di ruang kelas, tidak dilarang bicara, tidak ada pengelompokan atas dasar tingkat kecerdasan.

b. Adanya suasana penuh kasih sayang, hangat, hormat dan terbuka. Guru menangani masalahmasalah perilaku dengan jalan berkomunikasi secara pribadi dengan murid yang bersangkutan, tanpa melibatkan kelompok.

c. Adanya kesempatan bagi guru dan murid untuk bersamasama mendiagnosis peristiwaperistiwa belajar, artinya murid memeriksa pekerjaan mereka sendiri, guru mengamati dan mengajukan pertanyaan-pertanyaan.

d. Pengajaran yang bersifat individual, sehingga tidak ada tes ataupun buku kerja

e. Guru mempersepsi dengan cara mengamati setiap proses yang dilalui murid dan membuat catatan dan penilaian secara individual, hanya sedikit sekali diadakan tes formal.

f. Adanya kesempatan untuk pertumbuhan professional bagi guru, dalam arti guru boleh menggunakan bantuan orang lain termasuk rekan sekerjanya.

g. Suasana kelas yang hangat dan ramah sehingga mendukung proses belajar yang membuat murid nyaman dalam melakukan sesuatu.

Selanjutnya perlu untuk diketahui, bahwa penelitian tentang efektivitas model ini menunjukkan adanya perbedaan dengan proses pendidikan tradisional dalam hal kreativitas, dorongan berprestasi, kebebasan dan hasil-hasil yang bersifat afektif secara lebih baik. Akan tetapi dari segi pencapaian prestasi belajar akademik, pengajaran tradisional lebih berhasil dibandingkan poses pendidikan terbuka ini.

\section{Cooperative Learning atau Belajar Kooperatif}

Belajar kooperatif merupakan fondasi yang baik untuk meningkatkan dorongan berprestasi murid. Dalam prakteknya, belajar kooperatif memiliki tiga karakteristik:

a. Murid bekerja dalam tim-tim belajar yang kecil (4 - 6 orang anggota), dan komposisi ini tetap selama beberapa minggu.

b. Murid didorong untuk saling membantu dalam mempelajari bahan yang bersifat akademik dan melakukannya secara berkelompok.

c. Murid diberi imbalan atau hadiah atas dasar prestasi kelompok.

Adapun teknik-teknik dalam belajar koperatif ini ada 4 (empat) macam, yakni:

\section{Team Game Tournament}

Dalam teknik ini murid-murid yang kemampuan dan jenis kelaminnya berbeda disatukan dalam tim yang terdiri dari empat sampai lima orang anggota. Setelah guru menyajikan bahan pelajaran, lalu tim mengerjakan lembaran-lembaran kerja, saling mengajukan pertanyaan, dan belajar bersama untuk persiapan menghadapi perlombaan atau turnamen yang diadakan sekali seminggu. Dalam turnamen penentuan anggota tim berdasarkan kemampuan pada minggu sebelumnya. Hasilnya, murid-murid yang berprestasi paling rendah pada setiap kelompok memiliki peluang yang sama untuk memperoleh poin bagi timnya sebagai murid yang berprestasi paling tinggi. Adapun jalannya turnamen adalah para murid secara bergantian mengambil kartu dan menjawab pertanyaan-pertanyaan yang tertera pada kartu itu, yakni pertanyaan yang sesuai dengan materi yang telah dipelajari selama seminggu itu. Pada akhir turnamen, guru menyiapkan lembar berikut tentang tim-tim yang berhasil dan skor-skor tertinggi yang dicapai.

Meskipun keanggotaan tim tetap sama, tetapi tiga orang yang mewakili tim untuk bertanding dapat berubah-ubah atas dasar penampilan dan prestasi masing-masing anggota.

Jurnal Sikola: Jurnal Kajian Pendidikan dan Pembelajaran Vol. 2, No. 3, Th. 2021 
Misalnya saat ini prestasi murid rendah dan ia bertanding dengan murid lain yang kemampuannya serupa, maka minggu berikutnya ia bisa saja bertanding melawan murid-murid yang berprestasi tinggi manakala ia menjadi lebih baik.

\section{Student Team Achievement Divisions}

Teknik ini menggunakan tim yang terdiri dari empat sampai lima orang anggota, akan tetapi kegiatan turnamen diganti dengan saling bertanya selama lima belas menit, dimana pertanyaanpertanyaan yang diajukan terlebih dulu disusun oleh tim. Skorskor pertanyaan diubah menjadi skor-skor tim, skor-skor yang tertinggi memperoleh poin lebih dari pada skor-skor yang lebih rendah, disamping itu juga ada skor perbaikan.

\section{Jigsaw}

Murid dimasukkan ke dalam tim-tim kecil yang bersifat heterogen, kemudian tim diberi bahan pelajaran. Murid mempelajari bagian masing-masing bersama-sama dengan anggota tim lain yang mendapat bahan serupa. Setelah itu mereka kembali ke kelompoknya masing-masing untuk mengajarkan bagian yang telah dipelajarinya bersama dengan anggota tim lain tersebut, kepada teman-teman dalam timnya sendiri. Akhirnya semua anggota tim dites mengenai seluruh bahan pelajaran. Adapun skor yang diperoleh murid dapat ditentukan melalui dua cara, yakni skor untuk masing-masing murid dan skor yang digunakan untuk membuat skor tim.

\section{Group Investigation}

Disini para murid bekerja di dalam kelompok-kelompok kecil untuk menanggapi berbagai macam proyek kelas. Setiap kelompok membagi tugas tersebut menjadi sub-sub topik yang dibebankan kepada setiap anggota kelompok untuk menelitinya dalam rangka mencapai tujuan kelompok. Setelah itu setiap kelompok mengajukan hasil penelitiannya kepada kelas. Berdasarkan penelitian, teknik-teknik belajar kooperatif pada umumnya berefek positif terhadap prestasi akademik. Selain itu teknik ini juga meningkatkan perilaku kooperatif dan altruistic murid. Dengan demikian dapat disimpulkan bahwa teknik ini merupakan teknik mengajar yang efektif untuk mencapai tujuan instruksional kelas.

\section{Independent Learning (Pembelajaran Mandiri)}

Pembelajaran Mandiri adalah proses pembelajaran yang menuntut murid menjadi subjek yang harus merancang, mengatur dan mengontrol kegiatan mereka sendiri secara bertanggung jawab. Proses ini tidak bergantung pada subjek maupun metode instruksional, melainkan kepada siapa yang belajar (murid), mencakup siapa yang memutuskan tentang apa yang akan dipelajari, siapa yang harus mempelajari sesuatu hal, metode dan sumber apa saja yang akan digunakan, dan bagaimana cara mengukur keberhasilan upaya belajar yang telah dilaksanakan (Dahar, 2011).

Dalam pelaksanaannya, proses ini cocok untuk pembelajaran di tingkat atau level perguruan tinggi, karena menuntut kemandirian yang tinggi dari peserta didik. Di sini pendidik beralih fungsi menjadi fasilitator proses belajar, bukan sebagai penentu proses belajar. Meski demikian, pendidik harus siap untuk menjadi tempat bertanya dan bahkan diharapkan pendidik betul-betul ahli di bidang yang dipelajari peserta. Agar tidak terjadi kesenjangan hubungan antara peserta dan pendidik, perlu dilakukan negosiasi dalam perancangan pembelajaran secara keseluruhan.

Perancangan pembelajaran ini merupakan alat yang fleksibel tetapi efektif untuk membantu didik dalam penentuan tujuan belajar secara individual. Tanggung jawab peserta didik dan pengajar harus dibuat secara eksplisit dalam perancangan pembelajaran. Partisipasi para peserta didik dalam penentuan tujuan belajar akan membuat mereka lebih berkomitmen terhadap proses pembelajaran. 


\section{Student Centered Learning (Belajar yang Terpusat pada Siswa)}

Student Centered Learning atau disingkat SCL merupakan strategi pembelajaran yang menempatkan peserta didik secara aktif dan mandiri, serta bertanggung jawab atas pembelajaran yang dilakukan. Dengan SCL peserta diharapkan mampu mengembangkan ketrampilan berpikir secara kritis, mengembangkan system dukungan social untuk pembelajaran mereka, mampu memilih gaya belajar yang paling efektif dan diharapkan menjadi Life Long Learner dan memiliki jiwa entrepreneur. Sama seperti model sebelumnya, SCL banyak diterapkan dalam system pendidikan di tingkat Perguruan Tinggi. Dengan SCL siswa memiliki keleluasaan untuk mengembangkan segenap potensinya (cipta, karsa dan rasa), mengeksplorasi bidang yang diminatinya, membangun pengetahuan dan mencapai kompetensinya secara aktif, mandiri dan bertanggung jawab melalui proses pembelajaran yang bersifat kolaboratif, kooperatif dan kontekstual.

\section{Collaborative Learning (Pembelajaran Kolaboratif)}

Prinsip dari Pembelajaran Kolaboratif adalah bahwa pembelajaran merupakan proses yang aktif. Siswamengasimilasi informasi dan menghubungkannya dengan pengetahuan baru melalui kerangka acuan pengetahuan sebelumnya. Pembelajaran memerlukan suatu tantangan yang akan membuka wawasan para siswauntuk secara aktif berinteraksi dengan temannya. Di sini siswaakan mendapatkan keuntungan lebih jika mereka saling berbagi pandangan yang berbeda dengan temannya.

Pembelajaran terjadi dalam lingkungan sosial yang memungkinkan terjadinya komunikasi dan saling bertukar informasi, yang akan memudahkan siswamenciptakan kerangka pemikiran dan pemaknaan terhadap hal yang dipelajari. Siswa ditantang baik secara sosial maupun emosional ketika menghadapi perbedaan perspektif dan memerlukan suatu kemampuan untuk dapat mempertahankan ide-idenya. Dengan demikian melalui proses ini siswabelajar menciptakan keunikan kerangka konseptual masing-masing dan secara aktif terlibat dalam proses membentuk pengetahuan. Adapun prosedur pembelajaran kolaboratif adalah sebagai berikut:

1) Guru menjelaskan topik yang akan dipelajari

2) Guru membagi kelas menjadi kelompok-kelompok kecil yang terdiri dari 5 orang

3) Guru membagi lembar kasus yang terkait dengan topik yang dipelajari

4) Siswadiminta membaca kasus dan mengerjakan tugas yang terkait dengan persepsi dan solusi terhadap kasus

5) Siswadiminta mendiskusikan hasil pekerjaannya dalam kelompok kecil masing-masing dan mendiskusikan kesepakatan kelompok

6) Masing-masing kelompok mempresentasikan hasil diskusi kelompoknya dalam kelas dan meminta kelompok lain untuk memberikan tanggapan.

\section{Competitive Learning (Pembelajaran Kompetitif)}

Prinsip pembelajaran ini adalah memfasilitasi siswasaling berkompetisi dengan temannya untuk mencapai hasil terbaik. Kompetisi dapat dilakukan secara individual maupun kelompok. Kompetisi individual berarti siswaberkompetisi dengan dirinya sendiri dibandingkan dengan pencapaian prestasi sebelumnya. Kompetisi kelompok dilakukan dengan membangun kerjasama kelompok utuk mencapai prestasi tertinggi. Prosedur proses pembelajaran kompetitif adalah sebagai berikut:

1) Guru menjelaskan tujuan pembelajaran

2) Guru membagi kelas menjadi kelompok-kelompok kecil dengan jumlah anggota $5-7$ orang

3) Guru menjelaskan prosedur tugas yang akan dikompetisikan dan standar penilaiannya

4) Guru memfasilitasi kelompok untuk dapat mengerjakan tugas dengan sebaik-baiknya

5) Masing-masing kelompok menunjukkan kinerjanya 
6) Guru memberikan penilaian terhadap kinerja kelompok berdasar standar kinerja yang telah disepakati

\section{Case Based Learning (Pembelajaran Berdasar Kasus)}

Prinsip dasar dari metode ini adalah memfasilitasi siswauntuk menguasai konsep dan menerapkannya dalam praktek nyata. Dalam hal ini analisis kasus yang dikuasai tidak hanya berdasarkan common sense melainkan dengan bekal materi yang telah dipelajari. Pada akhirnya metode ini memfasilitasi siswauntuk berkomunikasi dan berargumentasi terhadap analisis suatu kasus. Prosedur yang dilakukan dalam metode ini adalah:

1) Guru menjelaskan tujuan pembelajaran dan metode yang akan digunakan

2) Guru meminta siswamempelajari konsep dasar yang berkaitan dengan tujuan pembelajaran, dengan cara membaca buku teks yang membahas materi tersebut.

3) Guru membagikan lembar kasus yang telah dipersiapkan, dimana kasus ini haruslah relevan dengan tujuan dan materi pembelajaran

4) Guru membagikan lembar pertanyaan yang harus dijawab oleh siswaberkaitan dengan pembahasan kasus tersebut. Pertanyaan harus disusun sedemikian rupa sehingga menjadi panduan siswauntuk dapat menganalisis kasus berdasarkan konsep dasar yang telah dipelajari

5) Guru meminta masing-masing siswamempresentasikan hasil analisis kasusnya. Siswadan guru dapat memberikan tanggapan terhadap presentasi yang disajikan. Pada intinya, pembelajaran dengan SCL sangat bertentangan dengan proses pembelajaran konvensional yang cenderung Teacher Centered Instruction, yakni proses pembelajaran yang mengandalkan guru atau guru sebagai sentralnya. Di sini nampak aplikasi dari aliran humanistik, yang sangat 'memanusiakan' peserta didik.

\section{Kesimpulan}

Psikologi humanistik sangat relevan dengan dunia pendidikan, karena aliran ini selalu mendorong peningkatan kualitas diri manusia melalui penghargaannya terhadap potensi-potensi positif yang ada pada setiap insan. Seiring dengan perubahan dan tuntutan zaman, proses pendidikan pun senantiasa berubah. Dengan adanya perubahan dalam strategi pendidikan dari waktu ke waktu, humanistic memberikan arahan yang signifikan dalam pencapaian tujuan ini. Teori belajar humanistik merupakan proses belajar yang harus berhulu dan bermuara pada manusia itu sendiri. Dalam teori belajar humanistik, belajar dianggap berhasil jika si pelajar memahami lingkungannya dan dirinya sendiri. Siswa dalam proses belajarnya harus berusaha agar lambat laun ia mampu mencapai aktualisasi diri dengan sebaik-baiknya. Aliran humanistik memandang bahwa belajar bukan saja sekedar pengembangan kualitas kognitif saja, melainkan juga sebuah proses yang terjadi dalam diri individu yang melibatkan seluruh bagian atau domain yang ada. Domain-domain tersebut meliputi ranah, kognitif dan psikomotor. Pendekatan humanistik dalam pembelajaran menekankan pentingnya emosi atau perasaan, komunikasi yang terbuka, dan nilai-nilai yang dimiliki oleh siswa. Psikologi humanistik memberi perhatian atas guru sebagai fasilitator untuk memberi kemudahan belajar dan berbagai kualitas fasilitator. Implikasi kecerdasan ganda sebagai bagian dari teori humanistik adalah sebagai berikut: Pendidikan harus memerhatikan semua kemampuan intelektual, pendidikan harusnya individual, memotivasi siswa, sekolah memfasilitasi siswa mengembangkan inteligensi ganda, evaluasi proses harus lebih kontekstual, proses pembelajaran dapat terjadi dimana dan kapan saja. 


\section{Daftar Pustaka}

Abdah, M. G. (2019). Ragam Pendekatan dalam Pengembangan Kurikulum Pendidikan Agama Islam (PAI). FONDATIA, 3(1), 27-41. https://doi.org/10.36088/fondatia.v3i1.158

Aradea, R., \& Harapan, E. (2019). Pengaruh Penerapan Teori Belajar Humanistik Terhadap Hasil Belajar Mahasiswa Pada Mata Kuliah Kewirausahaan. JMKSP (Jurnal Manajemen, Kepemimpinan, Dan Supervisi Pendidikan), $4(1)$, https://doi.org/10.31851/jmksp.v4i1.2479

Aziz, A. (1995). Pokok - Pokok Keterampilan Mengajar. Surabaya: FBS UNESA.

B. Uno, H. (2008). Orientasi Baru dalam Psikologi Pembelajaran. Jakarta: PT. Bumi Aksara.

Budiningsih, A. (2005). Belajar dan Pembelajaran. Jakarta: PT. Rineka Cipta.

Dahar, R. W. (2011). Teori-Teori Belajar dan Pembelajaran. Jakarta: Erlangga.

Dakir, D. (1993). Dasar-dasar Psikologi. Yogayakarta: Pustaka Pelajar.

Eggy, F. (2020). Digitalisasi Dunia Pendidikan? Humanisme Digital sebagai Poros Pembangunan Manusia. Malang: UMM Press.

Herpratiwi, H. (2009). Teori Belajar dan Pembelajaran. Bandar Lampung: Universitas Bandar Lampung.

Nursikin, M. (2016). Aliran-aliran Filsafat Pendidikan dan Implementasinya Dalam Pengembangan Kurikulum Pendidikan Islam. Attarniyyah, 1(2). https://doi.org/https://doi.org/1DOI: https://doi.org/10.18326/attarbiyah.v1i2.303-334

Rachmahana, R. S. (2008). Psikologi Humanistik dan Aplikasinya dalam Pendidikan. Jurnal ElTarbawi, 1(1), 99-114. https://doi.org/10.20885/tarbawi.vol1.iss1.art8

Rahmasari, D. (2012). Peran Filsafat Eksistensialisme terhadap Terapi Eksistensial-Humanistik untuk Mengatasi Frustasi Eksistensial. Jurnal Psikologi Teori Dan Terapan, 2(2), 141. https://doi.org/10.26740/jptt.v2n2.p141-148

Sukmadinata, N. S. (2007). Landasan Psikologi Proses Pendidikan. Bandung: Rosda Karya.

Sylvia, I., Anwar, S., \& Khairani, K. (2019). Pengembangan Instrumen Penilaian Autentik Berbasis Pendekatan Authentic Inquiry Learning Pada Mata Pelajaran Sosiologi di Sekolah Menengah Atas. Jurnal Socius: Journal of Sociology Research and Education, 6(2), 103. https://doi.org/10.24036/scs.v6i2.162

Wasitohadi, W. (2012). Pragmatisme, Humanisme Dan Implikasinya Bagi Dunia Pendidikan Di Indonesia. Satya Widya, 28(2), 175. https://doi.org/10.24246/j.sw.2012.v28.i2.p175-190 